\title{
もら一つの「家族と文化論」
}

\section{一階層的家族文化論 -}

\section{清 水 新二}

Key words : 文化、階層、家族ライフスタイル

\section{はじめに}

「文化と家族」と題する今回の第 6 回家族社会学大会シンポジウム（1996, 金城学院大学）は、比較 社会学的アプローチによってジェンダー論や東アジアの家族論を展開してきた瀬地山角氏、これまで教 育社会学を領域にして女性や家族の問題を階層研究アプローチによってとらえてきた片岡栄美氏、社会 心理学的観点から世代間にみられる消費行動・意識や価値意識に関する異同の検証に力を入れてきた中 村雅子氏、の三氏をシンポジストに迎えて開催された。それぞれの個別報告は、本稿に引き続き揭載さ れているため、あえてその要旨を紹介することは割愛したい。むしろ司会の任にあたった者として、今 なぜ、文化と家族なのか? このトピックに関して短い私見を述べて、以下の各報告の露払いとしたい。

シンポジスト企画者によれば、前回の日本家族社会学会大会シンポジウム「社会階層と家族」の設定 意図であった、「個人・家族・社会」を貫通する切り口から見えてくる家族像の把握を継承した今回は、 「文化と家族」という切り口を通して、他の社会学領域とクロスオーバーさせることで見えてくる日本 家族の特質、家族变動、家族の現在状況はどのようなものであるかを探ることにある。そして「各サブ システム間のボーダーレス化」現象（渡辺、1996）は、家族と他の社会システムとの関連性を問うこと になるという。シンポジウム・コーディネーターたちのこうした企画意図が、今回のシンポジウムでど れほど達成されたかは不確かであるが、いま少し今回のシンポジウムテーマの背景を紹介しておけば二 つの事柄が指摘される。

\section{1. 古くて新しい問題：他の社会システムとの関連性}

第一には家族と家族をとりまく環境的変化である。外部体系の重要性というテーマ自体は、新しそう で古い問題であるが、今回のシンポジウムで取り上げる観点はやはり古くて新しい問題といえる。家族 と外部体系の関連性を問う研究例はこれまでも少なからずあり、わが国の村落構造研究や同族団研究を 始めとし、中国の宗族、南スラブ社会のザドルガあるいはナヤールの母系制家族やイスラエルのキブッ 等々にみられる家族の文化論、産業社会と核家族孤立論、E.BottやH.Rodman らによる社会的ネット ワークと夫婦役割構造の関連性研究あるいは文化的脈略における夫婦の勢力構造研究、また社会変動と 家族変動の関連性に関する開放系／閉鎖系／半閉鎖体系論議など、数え上げれば枚挙にいとまがないほ どである。既に1970年代半ば、わが国の著名な二人の家族社会学者は、日本の家族社会学が直面してい る課題として家族と外部体系の関連性の問題に言及している（森岡，1974；上子，1975）。当然、今な 
ぜ、家族と文化なのか、なぜ他の外部社会システムとの関連性なのか？ということになる。

国際化は政治経済のみならず、われわれの日常生活レベルにも否応なく押し寄せている。国際結婚は 言うにおよばず、六本木や上野で有名になった中高生も巻き込んだ違法薬物のミ二国際マーケットなど に観察されるとおり、日常的な異文化接触の機会はつとに增大している。進捗著しい情報化もまた、時 間・空間の意味や機能の変容をもたらし、その結果人間関係やコミュニケーションのありようにも大き な影響を与えつつあり、これが家族の時間・空間の意味機能に影響を与え多くの社会システムに変容を 迫っている。こうしたシステム変化の要請とそれへの対応、対処上の様式差は、とりわけ家族・親族世 界においてジェンダ一間、世代間の葛藤さえ生起させている。もちろん高齢化、少子化、晚婚化、非婚 化などの人口学的要因の変化が引き起こす家族行動・価值意識の変容も言わずもがなである。継承と変 化という社会的現実の二面性を勘案した上でも、現在の潮目は変化の潮流が速まっていることは疑い得 ないところであろう。

さらに注目すべき点は、これまで家族社会学の通常的発想である社会システムの変化が家族システム の変化を誘導するという図式ではとらえきれない異なるパターンによって、家族をめぐる変動が生じて いる側面である。収斂理論 (convergence theory)によって、産業化の過程で世界の多くの家族変動は 夫婦家族制イデオロギーを主導的媒介項として夫婦家族制という共通の一つの家族様式へむかうと予測 したグード (Goode, 1963) でさえも、当時から次のように述べていた。すなわち、「産業的な諸力が あらゆるものをその尺度にあわせて形づくるのだと仮定することはできない。このような圧力に対して 家族体系が示す抵抗自体が、とりもなおさず、家族体系が一組の力として独立していることを物語るも のに他ならない。それは政治や経済の大きな変化が結局はこのような抵抗を押し切ってしまうというこ ととは別問題である」(Goode，1964）。さらに離婚問題論では、「安定した高離婚率」という一定の変 動方向を示しつつも、その社会的反作用様式、社会的対応スタイル、離婚の歴史と伝統・文化などを加 味して、分散理論 (divergence theory) とは言わないまでも分散型の理論を取り込んでいる（Goode, 1993）。現在生起しつつある家族と社会のシステム変化の特徵は、国際化、情報化、人口構造変動など の外部的環境要因によって促されているのみならず、むしろ家族や個人、とりわけ個人のサイドの生活 ニースと生活選好性（価値意識、ライフスタイル）の変化によって社会システムの側の変化が要請され ている点にある。この点は、現時点で家族と他の社会システムとの関連性を論議する上で、どれほど強 調してもし過ぎることのない重要な局面である。

近年家族社会学でも従来とは異なる観点から「家族と労働・職域」問題が関心を引いているのは、こ うした新たな状況を反映してのことである（木本，1995）。また家族と他の社会システムとの関係が新 たな関係局面に入ってきたことによって、私事化論議も個別化論議や個人ネットワーク論議を介在させ て、いよいよ脱私事化 (deprivatization) への方向と向かっていくだろう（清水, 1991 ; 礒田・清水, 1991 ; Holstein and Gubrium, 1995 ; 野沢, 1992)。

さらに前回大会のシンポジウム「社会階層と家族」における論議と接合すれば、階層測定の単位を家 族ないしは世帯にとるのかそれとも個人に求めるのか、夫と妻のどちらをないしは双方をとるべきか、 「女性」は独立した階層単位となりうるのか、といった諸問題は、単に家族をめぐる現象に対してより 有効な説明力をもつ測定用具の工夫の要（Smith and Graham, 1995）といった研究技術的問題を超 
えて、階層研究に根元的な問題を突きつける新たな状況が出現している証左であり、改めて「現代社会 において意味のある階級・階層」を求め発見せねばならないとの指摘も（盛山、1996）、根を同じくす るものであろう。

今後益々家族世界の問題は、家族と他の社会システムとの関連性を改めて問うことが重要な課題とな ろう。家族の歴史的変動への家族社会学的関心は今や舞台が一回りし始め、再度かつてのように「家族 研究をとおして社会が見える」(清水、1992) ようになってきた。「今、家族の社会学がおもしろい」由 縁である。ただし当時筆者が「家族研究をとおして社会が見える」とフレーズ化した意味は、単に家族 と外部システムとの関連性を視野に置くことを意味するだけではなかった。むしろ、戦後の日本家族社 会学に特徴的であった、急速な法制的社会的な社会・家族変動に対する濃密な歴史的関心を指し示すも のとして、またこの家族の制度的变動を注視するインディケーターとして家族内部構造に焦点を当てた 事実によってこそ「家族研究をとおして社会が見えた」事情を強調したかったからである。いわば家族 の制度論的アプローチと集団論的アプローチが結びついた時、当時の社会歴史状況下にあって「社会が みえた」といってよい。

\section{2. 新しい家族パラダイムの対象と方法}

第二には、この間に以前とは異なる家族研究に関する新しい研究パラダイムが勃興し、家族研究の方 法と対象において確実な変化を体験したからである。言わずもがなの感があるが、「これまでのアプロー チ」とラベルを貼られたのは、プライベートな世界として家族の存在をアプリオリに想定しこれを出発 点として家族集団ないしは家族システムの中における成員間の相互作用を、あるいは家族集団ないしは 家族システムと他の社会サブシステムの関係性を対象に設定し、それらの社会的相互作用の諸結果とし て個人の存在のありようを理解するというアプローチである。もっとも戦後日本家族社会学会において、 プライベートな生活集団としての家族を措定できるようになったこと自体は、現実上も研究上も大きな 歴史的展開の一コマであったことは想起されねばならぬ事実であろう。これに対して、一方で分析の視 点と主要単位を個人に置いたうえで、他方で家族集団ならびに家族関係を、個人の生活・欲求ニーズの 充足過程の一つとして措定することを通して、シンポジウム企画者の言を借りれば「家族を方法的に解 体する試み」が押し進められてきた。言葉を変えれば、個人の生活・欲求ニーズの充足をはかるために、 ある時は戦略的にある時は仕方なしに人生の道行き（life course）の折々に人が選択する生活様式の一 つとして家族をみる、いわば生活者の視点からする家族の相対化である。この点では前記の「とりわけ 個人のサイドの生活ニーズと生活選好性（価值意識、ライフスタイル）の変化によって」、今度は家族 システムの側の変化が要請されている側面ともいえる。

こうした側面をよりよく把握するために、なお概念的精緻化に課題は残るものの家族社会学はこれま で「私事化」、「個人化」、「個別化」、「多様化」、「ライフスタイル化」などのキータームを備え始め てきている。ここでは「家族の個人化も多様化も、たとえば社会階層という切りロで見ることで、はじ めて一つの明瞭な像をむすぶことができるはず」〔渡辺, 1996, p.5]との前年度シンポジウム司会者 の指摘に共感しつつ私自身が今回の司会を引き受け、また司会を終えてみて改めて「家族と文化」のト ピックを私なりにどう考えてみたのかについて簡単に記したい。各シンポジストからの問題提起に加え 
て、「社会階層と家族」という前年度シンポジウムのテーマも想起しながら「文化と家族」論議に関す るもう一つの問題提起をしてみたい。

なお蛇足ながら付け加えれば、おそらく今後個人化、個別化などの家族的文脈を踏まえたうえで、 “個別的でありつつ共同的でもある”家族の関係性のあり様をめぐって、新たな「共同性」や「統合性」 の概念的、実態的解明の課題がすぐその後に控えているものと考えられる。論識としてではなく、実態 としてこれら家族の多様性や個人化・個別化を既に広箸に体悇済みの社会、すなわちアメリカでは早く も家族の全体性や家族世界をどう考えたらよいのかをめぐって詥争が始まっている（JMF、58巻 3 号 特集参照）。わが国の家族社会学研究者にとっても目配りしておくべき辢であろう。

\section{3 . 家族、文化、そして階層}

家族と文化といえば、やはり階猬的視点を抜きには語れない。ある文化の中核的担い手として、被数 下位文化のそれぞれの担い手として、あるいはまた文化変容や家族イデオロギーの変容渦程においても 社会経済階首变数は重要な影䇾を及ぼすことになる。前述のグードによる産業化と家族变動パターンお よび離婚の世界的变動パターンに関する膨大な文化比較分析にもその基本視角として階㾍分析が取り込 まれていたし、サスマンとシュタインメッッ（Sussman and Steinmetz, 1987) 繓算の家族社会学八 ンドブックでも家族生活の多様性分析軸は、アメリカゆえ当然にも第一にエスニシティ、そしてその第 二に社会㳻屏が位置つけられている。ハビトス的な文化伝承のエージェントとしての家族に注目し、と

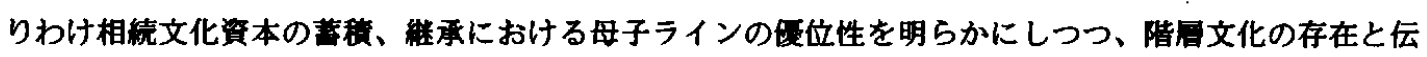
承性を問うた、今回のシンポジウムにおける片岡の報告もこの分析視角に近い。

フルデュー（Bourdieu, 1979）に做って片岡（1992）は、文化はヒエラルキー化し社会的ヒエラル キーと対応しつつ、したがって文化消費は階級・階層の指摽となっているという。そうであるならば、 このことは次のようなことを意味しまいか。すなわち、ひとたびハビトス的で筥自覚な継承性という視 点から離れてみれば、䅹古事やコンサートのみならず、昨今話題の家笑ライフスタイルの多粎性もが文 化消費の対象となっている可能性が考えられ、ある特定階首の、あるいはまたこの特定階層参入上の文 化的な象幑的記号やコードになっている可能性である。とりわけわれわれ自身一つの階層文化を樮成す る研究者社会 (academic community) が、“新しい”家族ライフスタイル論議を展開する场合、こう した問題意識は重要となろう。

政論、こうした「文化による差異化戦略」といった記号論的解积に対しては、ぎりぎりの選択であっ たか十分ゆとりのある選択であったかは問わないまでも、実際にそうしたライフスタイルを生きている 当事者（善積、1992）からは、おそらくクレイムが予想される。にもかかわらず、往々社会的現実の構 築過程は当事者以上に、専門家や学会等、当該問題に関心を寄せる人々からの定義や整理が影警力をふ るう。そもそも人々の日常生活を文化という視点から切るといった今回のシンポジウムの営為自体がそ うである。

中村（1997）による価値意識の世代的連経・不連綂性類型に示唆されて付け加えれば、個人化やライ フスタイル化といった多様で先進的な家族ライフスタイルをとる階層文化の担い手ないしはソーシャル セクターは、その比較的恵まれた階屏性からしてこれを一つの階楣的下位文化として考えてみたい。こ 
のソーシャルセクターは中村言うところの、子どもへの家族文化伝達意識が明確で、世帯年収も高い階 層に多くみられるという「モザイク型」にも共通する特徽が予想されるが、他方その多様性志向からす れば、むしろ世代間継承が弱くかつ同世代でも大きな差遣がみられるという「選択縁型」により近いと いえるだろう。また中村は世代間価値意識伝承の日米比較の結果を通して、あくまでも相対的ながら日 本では洒値意識の伝承意識が嗳味で、子どもの自主性を尊重するいう様式が優勢であるとの知見を得て いる。そしてこのことが結果的に「洒值観の多様化」それ自体を促進していると解釈できるとみる、興 味ある指摘をしている。日本の価値観の变化には㩆著なものがあるが、いま少し価値伝承意識が明確で あったならさほどに急速な価値観の变化がもたらされたかどうか筑問なしとしない、とも付言している。

ただし以上の論議はあくまで諭議であって、聿態そのものではない。家族個別化と私事化をめぐるわ れわれの再調査結果（磁田他、1996）に依りつつ言えば、これらの論議における多様なライフスタイル への志向性は「中居」から「中層の上」家族を中心に観察されるだろうとの仮定を出発点とするもので ある。むしろ上述した論点は検証されるべき性質のものである。家族と文化の問題を改めて階同性の、 そして多分に地域性の視点を絡めてアプローチする必要がある。その際、これまでの垂直的な階層概念 に加えて、社会的カテゴリーあるいはソーシャル・セクターといった水平的な概念要素の組み込みも検 討されてしかるべきだろう。男と女の間でカテゴリ一移動が考えにくいにもかかわらず「女性は一つの 階層を樓成しうるか否か」との問いかけを含めて、これまでの階屏研究からすれば、まさに扰戦的課題 というしかない。「グレイカラー」「階居ボーダーレス」あるいは「一億総中流社会」などの用語の商 否は別にして、少なくとも日本社会において階層間格差が低娍してきており、これに対応するかのよう に階層問題への関心が希薄化しているという以上、改めて「現代社会において意味のある階級・階君」 を求め発見せねばならないという指摘（盛山、1996）には、こうした挑戦的課題が含まれてこその部分 があるはずである。また用って現代階層研究のブレイクスルーという䚌点からも、この批戦的課遉は戦 略的課題という側面も併せ持つことになるだろう。

国際化やボーダーレス化の家族への影签も、文化をめぐる持続性と変容性の問題も、こうした階局や 地域性の視点を大胆かつ慎重に組み込んだ「家族と文化」研究とリンクさせることによって、その社会 過程は一層動的かつ複眼的に解明されるに違いない。この点においてこそ、綎系（時代性）と横系（地 域性）を絡ませつつ家族の在りようや家族の文化を相対化した瀬地山（1997）の試みへと接合されるの である。ただし、社会の構成原理を家族的原理に求めるという「家族と文化」の静態的記述研究の側で も、学史の舞台を一回りさせて地域的、階居的文化差をさらに動態的にとらえる努力が呼応すべきであ ることはいうまでもない。この点においてこそ、瀬地山の試みは清水浩昭（1992）や杉岡（1996）の家 族に関する地域的、文化的な複局論的アプローチへと連なるチャネルを確保することになるだろう。

\section{4 . 自省的家族文化論}

ここで少し锶点を変えて、自省的にわれわれ家族研究者自身を関心対象に据えてみよう。前段では文 化の社会的ヒエラルキ一問題に関連させて、多様な家族ライフスタイルさえもが文化消費の対象となっ ている可能性について触れた。では家族ライフスタイルの多様性について活発に語るわれわれ家族研究 者自身の言説はどうみられるであろうか。「文化消費は階級・階居の指標」とみる立場からは、当然階 
層規定的なものとみなされるであろうが、そうした特定の理論的見方に立脚したわけではないものの、 筆者もかつて「家族研究の私事化傾向を越えて」と題する拙論においてわれわれ家族研究者が留意すべ き階層性について触れたことがある（清水，1992）。

家族の多様化あるいは選択可能なライフスタイル化といったことが話題となって久しい。集団の拡大 と個性の発達なしいは社会圈の交差を論じたジンメル（Simmel，1890）を引くまでもなく、この傾向 は近代社会全体の变化に符合して、一つの社会文化における統合的、支配的な一一少なくとも実際以上 にそう見えていたかも知れない一家族文化の輪郭が暧昧化し、これを構成してきた個々の家族の文化 的個性差が大きくなってゆく社会過程と明らかに連動するものである。ただここでもまた、家族の個性 差と並んで家族の文化的階層差が無視されてはならないだろう。多様な家族ライフスタイルの偏在性あ るいはライフスタイル選択における自発性に関して、われわれ家族研究者自身が階層的分化の視点をもっ てカウンターを当て続けることは、自省的観点から重要なことである。こうした観点を強調することで は大先輩にあたる布施（1990）の次のような指摘はあまりに鋭く、筆者自身にも耳が痛いところである。 「率直にいって、研究者が書斎にあって、今日の日本では中流に位置づくであろう生活水準と生活感覚 にもとづく思考を展開するとき（それは『白書』をつくる役人も同じだが）、今日の日本家族がかかえ ている問題状況が正確に把握されるとは思えない」。「家族と文化」を論ずることが文化消費行動かど うかはさておいて、われわれ家族研究者自らの階層規定的期待と “家族の現実、実態”として構築され るリアリティの緊張関係は、改めてわれわれを研究活動における原点へとたち帰らせる。

かつて「日本人は世界でもっとも結婚好きな国民」であると要約された高い婚姻率や低い生涯未婚率 も、同じ著者による改訂版では「1968年頃には、世界のトップレベルにあったそれが、最近では最低の レベルに近くなってしまった」と記述し直されている（湯沢、1973；1987）。若者の結婚忌避の風潮の みならず、適齢期人口の相対的減少という人口構造上の変化に着目する湯沢（1987）は、これがわが国 の将来において生涯独身主義者の増加につながるかは不明であるとしている。他方、価値観や人口学的 要因以外にも若者の独身主義ライフスタイルが親世代の経済的要因に大きく影響されているとみる研究 に宮本らのベビーブーマーの研究がある（宮本他、1995）。かつてであれば独立を期待さた年齢層にあっ ても、家計・家事を含めて経済的にも非経済的にも親の庇護下にある独身の若者が少なからず存在する ことから、これを現代に特有のライフステージとして「脱青年期」と命名してとり出した。そしてこの 新たなライフステージの出現の背景として、経済状況の好転、すなわち戦後の高度経済成長による各世 帯の経済資源性の増強に着目している。宮本は脱青年期の特徵が首都圈の経済的に恵まれたミドルクラ スの中に典型的に認められるとする一方で、「おしなべて広範な階層と地域に普及している」としてい るが（宮本，1995）、日本社会の景気後退が長引く中で脱青年期の行方は階層的偏在性の視点から大变 興味ある今後の動向であり、まさに全国調査の課題としても地道な継続的観察の対象であろう。

\section{おわりに}

最後にまったく異なる視点から、いま一つの自省的な家族研究課題を披露して終わりたい。振り返れ ば、20数年にも及ぶ家族社会学セミナーの時代を経て、家族社会学セミナーは1991年に学会化を図り、 既に 6 年の経過を見て今日に至っている。学会化に当たってはいろいろな意見が表明された。しかし、 
学会化翌年の日本家族社会学会としての第 1 回大会（甲南女子大学）の盛況、新規会員の増大などをみ るにつけ、学会化の選択は妥当なものであったというべきであろう。こうした学会化以降の過程で生じ た特徵を、私は「セミナー村の家族社会学」から「家族研究の社会学」へととらえている。真摰ではあ るが旧知の同空会的、家族的であった合宿形式のセミナー時代から、個体識別も次第に困難な匿名的な 全国学会への変貌である。このプロセスは、これまで家族社会学や家族に関する社会学研究に関心は抱 きつつも、村的、家族的な需囲気を色濃く漂わす家族社会学セミナーにはなんとなく気が置けると感じ てきた家族研究者（隣接領域の研究者も含めて）の、学会化を機とする積極的な参画によるところが大 きい。歓迎すべき傾向である。さらに昨今は理事選出制度問題に関しても、村からコスモポリタンへの 比重転換傾向が影を落としている。継承と変化、学会や組織にとって不可欠な求心性ならびに安定維持 と、拡散のリスクにもかかわらず新しい变革への挑戦的魅力。この両者のベクトルの評価と制御問題は、 学会化位相を成功裡に乗り切った日本家族社会学会の次なる課題であろう。

最後とはいいながらいささか現実的な話になったが、家族社会学会シンポジウム「家族と文化」を司 会するにあたって、シンポジストの方々と打ち合わせをしながら、つらつらと思いいたった印象である。 一つには、家族が文化の持続と変容のエージェントとしてどのように作用するのかというテーマとの構 造的共通性から、そして二つには、シンポジストの任を引き受けてくれた研究者の方々の家族社会学会 とのこれまでの関わり様（この点は昨年の大会シンポジウム一家族と階層一の場合も同様である）から して、変貌しつつある家族社会学研究をこれから実質的に担っていくのは、「セミナー村の家族社会学 研究者」以上に「家族研究の社会学者たち」なのだろうか、との思いを強く持たされたからである。シ ンポジウム「家族と文化」を司会してみての副産物であった。と同時に、会員の個体識別もままならな いという意味で階層輪郭の不明瞭化をきたした今日の日本家族社会学会においては、「家族社会学セミ ナーに育てられた」というかつてセミナ一時代に聞き慣れたフレーズのもつ実利性、すなわち家族社会 学セミナー時代からの「文化資本の継承と再生産」果実は、見かけ以上に生き続けているのでしょうか、 片岡さん? また家族社会学会の組織的変容の節目にあって、家族社会学セミナーの遗産としての意識、 行動を次の世代に伝達しない方が「適応的な戦略」となるのでしょうか、中村さん？あるいは欧米とも、 中国や朝鮮の文化とも違う、日本的な学会文化あるいは構成原理を今後どう展望したらいいのでしょう か、瀬地山さん?「日本家族社会学会と文化」論の展開も期待します。

\section{文嗝}

Bourdieu, P., 1979, La Distinction: Critique Sociale du Judgment, Minut. (石井洋二郎訳, 1990, 『ディスタンクシオン』 I, II, 藤原書店).

布施晶子, 1990,「家族社会学の現代的課題一变わりゆく家族にどう対処するか一」, 『家族社会学研究』， $2,48-56$.

Goode, W.J., 1963, World Revolution and Family Patterms, The Free Press.

Goode, W.J., 1964, Family, Prentice-Hall. （松原治郎・山村健訳, 1967, 『家族』, 至誠堂). Goode, W.J., 1993, World Changes in Divorce Patterns, Yale University Press.

Holstein, J.A. and Gubrium, J.F., 1995, "Deprivatization and the Construction of Demestic 
Life," Journal of Marriage and the Family, 57:4, 894-908.

礒田朋子・清水新二, 1991, 「家族の私事化に関する実証的研究」,『家族社会学研究』，3，16-27. 礒田朋子・清水新二・藤田道代, 1996, 「高学歴・有職女性とそのパートナ一の個別性と共同性一個別

性と共同性は共存するか一」, 第69回日本社会学会大会, 沖縄.

上子武次, 1975, 「家族社会学の二つの課題」、『社会学評論』, $25: 4,51-68$.

片岡栄美, 1992,「社会階層と文化的再生産」, 数理社会学編『理論と方法』, $7: 1,33-55$.

木本喜美子, 1995, 『家族・ジェンダー・企業社会』，ミネルヴァ書房.

宮本みち子, 1995, 「「脱青年期」の出現にみる少子化社会の親子のゆくえ」, 『季刊家計経済研究』,

$27,31-40$.

宮本みち子・岩上真珠・山田昌弘・米村千代・飯田和子, 1995,「ベビーブーマーのライフコースと世

代間関係」,『季刊家計経済研究』，25,9-67.

森岡清美, 1974, 「家族社会学の現代的課題」、『社会学評論』, $25: 2,2-17$.

中村雅子, 1997,「価値意識の世代間伝達に関する日米比較」，『家族社会学研究』，9，39-56.

野沢慎司，1992,「都市家族研究における新たなパースペクティブーパーソナルネットワーク論からの

再検討一」,『静岡大学人文学部人文論集』，42,53-76.

瀬地山角, 1997,「東アジア版「イエ社会論」へ向けて一家族の文化比較の可能性一」, 『家族社会学研

究』, $9,11-21$.

盛山和夫, 1996,「家族か個人か一階層単位とジェンダー一」,『家族社会学研究』，8，33-45.

清水浩昭, 1992,『高齡化社会と家族構造の地域性一人口变動と文化伝統をめぐって一』, 時潮社.

清水新二，1991，「家族精神保健論序説一現代家族の私事化状況をめぐって一」，『精神保健研究』，37， $137-150$.

清水新二, 1992,「家族研究の私事化傾向を超えて」，『家族社会学研究』，4，31-39.

Smith, T.H.and Graham, P.B., 1995, "Socioeconomic Stratification in Family Research," Journal of Marriage and the Family, 57:4, 930-940.

Simmel, G., 1890 (石川晃弘・鈴木春男訳, 1968) , 『社会的分化論一社会学的・心理学的研究』（世 界の名著47），中央公論社.

杉岡直人, 1996,「家族規範の変容」, 野々山久也・袖井孝子・篠崎正美編『いま家族に何が起こって いるのか』, ミネルヴァ書房, 47-68.

Sussman, M.B. \& Steinmetz, S.K., 1987, Handbook of Marriage and the Family, Plenum Press.

善積京子編，1992，『非婚を生きたい：婚外子の差別を問う』，青木書店.

湯沢雍彦，1973，『図説家族問題』，日本放送出版協会.

湯沢雍彦, 1987, 『図説現代日本の家族問題』，日本放送出版協会.

（しみず しんじ・国立精神神経センター精神保健研究所） 


\section{Family and Culture: Relevance to Social Stratification Theory}

Shinji Shimizu

Key words : culture, social stratification, family life-style

Discussions of diversity and family life-style are closely linked to the social process in which the dominant family pattern has gradually been replaced by an expansion of culturally diverse family structures. The discussion of family and culture, however, has been likely to be based more or less upon a generalization of a particular family life-style which covers the society as a whole. These two different discussions can be integrated through social stratification theory. Socio-economic variables are keys to understanding both the relationship between the family and the external social system, as well as the individuals who support certain family cultures or subcultures.

While the personal concerns reflecting our own private life definitely place in the core of our family studies, we should pay more attention to the influence from the external world such as the social stratification variable when discussing issues of the current family life-style.

\section{Family as a Basis of Organization: Toward a Comparative Study in East Asia}

Kaku Sechiyama

Key words : family system, corporate organization, East Asia

This paper discusses connections between traditional family systems and institutional organizations in three East Asian societies. As many "ie-soiety" theorists have noted, the family unit in Japan served as a structural model for various institutions, most notably business corporations, during the early period of modernization in Japan. The ie (stem family) system, which emphasized continuity and seniority, but allowed for a flexible system of adoption, provided businesses with a structure that maintained a high level of integrity among its employees based on a system of seniority.

Similar trends can be observed in both China and Korea. The preponderance of small businesses typical to Taiwan and Chinese diaspora stem from the traditional Chinese family system, which placed less emphasis on seniority among brothers. Likewise, Korean chaebols can be traced to the Korean family system, which placed a higher priority on blood relationships than the Japanese family system, and a greater emphasis on seniority than the Chinese family system. 